\title{
Karaititanga: Some Reflections on my Christology
}

If God had a face, what would it look like?

And would you want to see?

If seeing meant that you would have to believe

In things like heaven and in Jesus and the

saints and all the prophets?

Joan Osborne (1995)

\section{Christology in images}

Osborne's (1995) song calls to mind a profound and poignant question: what does the face of God look like? Furthermore: what does the face of Jesus, as God incarnate, look like? Does he look like me? Is he Māori? I recall images of Jesus in the homes of whānau and friends. One such image was of a 1950sstyle Jesus, with a European profile and baby blue eyes. He looked quite content in this image; this Jesus had not anticipated what was to come. This Jesus was white. In another illustration of Jesus, he is suffering, crowned with thorns, with a look of anguish and annihilation in his eyes - the weight of the world's sins, past, present, and future, crushing him. This Jesus was also white. Another such image is the iconic Sacred Heart of Jesus. In this image, the heart of Jesus is understood, by some, as a representation of Christ's love for humanity. The heart, pierced and bleeding, surrounded by thorns and crowned with the cross, radiates divine light. Again, this Jesus was white.

In the wharenui at my marae in Waiohau, there was a brass cross inside a wood and glass case which sat upon a small, high, shelf affixed to the central poupou at the back of the whare. The 
cross was old and tarnished. Below it was a very old, weathered, framed, picture of Jesus knocking on a door illustrating Revelation 3:20: "Behold, I stand at the door, and knock: if any man hear my voice, and open the door, I will come in to him, and will sup with him, and he with me" (KJV). Jesus stands dressed in a light-coloured alb-like tunic, with an elaborate cope, a gold crown, and a garland of greenery illuminated by a halo. Besides the crown, Jesus appears to be wearing liturgical garb. He holds in one hand an elegant lamp, and with the other hand knocks on a door, covered with overgrowth, suggesting that this door has been closed for a long time.

Interestingly the door does not have a doorknob. This old image was a battered print of William Holman-Hunt's 1853 painting (there were three versions painted), Light of the World. Concerning the absence of a doorknob Holman-Hunt (1905) declares that this represents "...the obstinately shut mind" (p. 350). Jesus knocks, but the individual must open the door from the inside. However, this Jesus is, again, white. 
Image 1: Holman-Hunt's, Light of the World, 1900-1904 version, Middlesex Chapel, St Paul's Cathedral, London

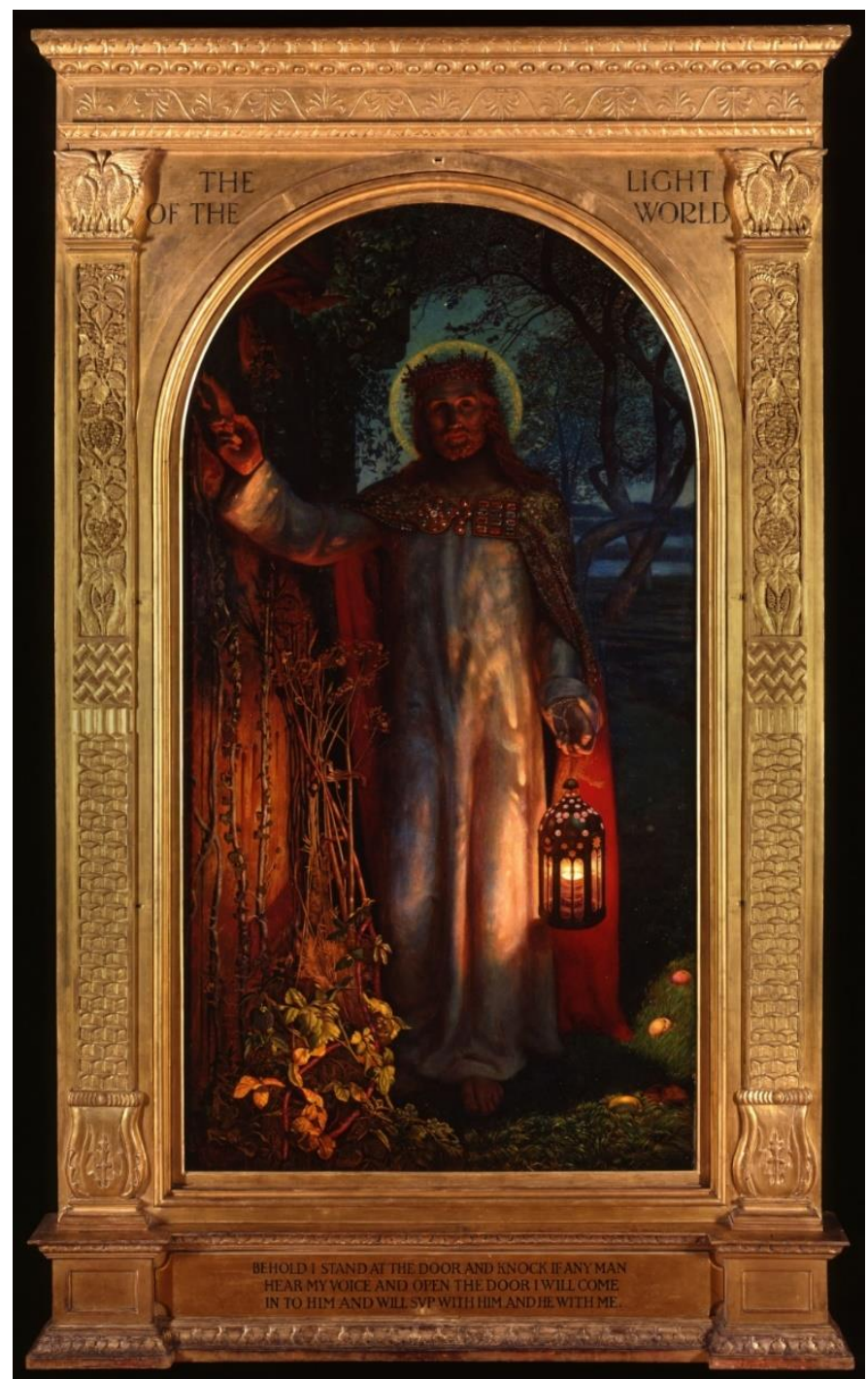

(Holman-Hunt, 1904-1905, n.p.). 
None of the images of Jesus that I have seen look middleEastern. It seems that Christological iconography reflects the culture of the artist: European artist $=$ European Jesus.

\section{Christology in words}

If Jesus comes to us in a way that we can recognise, what of a Māori Jesus? James K. Baxter's poem causes me to reflect on what a Māori Jesus might look like.

I saw the Maori Jesus

Walking on Wellington Harbour.

He wore blue dungarees, His beard and hair were long.

His breath smelled of mussels and paraoa.

When he smiled it looked like the dawn.

When he broke wind the little fishes trembled.

When he frowned the ground shook.

When he laughed everybody got drunk.

The Maori Jesus came on shore

And picked out his twelve disciples.

One cleaned toilets in the railway station;

His hands were scrubbed red to get the shit out of the pores.

One was a call-girl who turned it up for nothing.

One was a housewife who had forgotten the Pill

And stuck her TV set in the rubbish can.

One was a little office clerk

Who'd tried to set fire to the Government Buldings.

Yes, and there were several others;

One was a sad old quean;

One was an alcoholic priest

Going slowly mad in a respectable parish (Baxter, 1988, p. 347).

Brown's poem is a response to Baxter.

i AM the Māori Jesus

And i don't like

mussels and parāoa

Give me fish 'n' chips

with tomato sauce

Fresh white bread 
and loads of butter

Butter makes this country great

So feed my whenua

to the cows

for all i care (Brown, 2014, p. 48).

Contextualising my Christology into a Patuheuheu hapū (one of my hapū) milieu, this is my response to both Baxter and Brown.

\section{Patuheuheu Jesus}

I am the Patuheuheu Jesus

I go eeling and hunting

My knife is always sharp

My hinaki is always bursting

I don't eat wild pork, cos I'm a Jew

But I give it away to the old people

They make boil up and

pāpākiri thick with butter

At Easter time I walk

through the Horomanga

looking for a big fat kererū

In the pot it goes for Aunty

She's sick - even I can't heal her

It's her last supper, no wine

Just waikōhua and kūmara

Too sick to chew flesh

I salt and dry the eels in the sun

I don't eat eels, cos I'm a Jew

Koro and Nan eat it with rīwai and pūhā

I'm all about that manaaki life

Sometimes I scrub the shit

out of the toilets and unblock

the drains

Working at the marae

is hard work at times 


\section{Image 2: Some of my collection of religious iconography, Murupara}

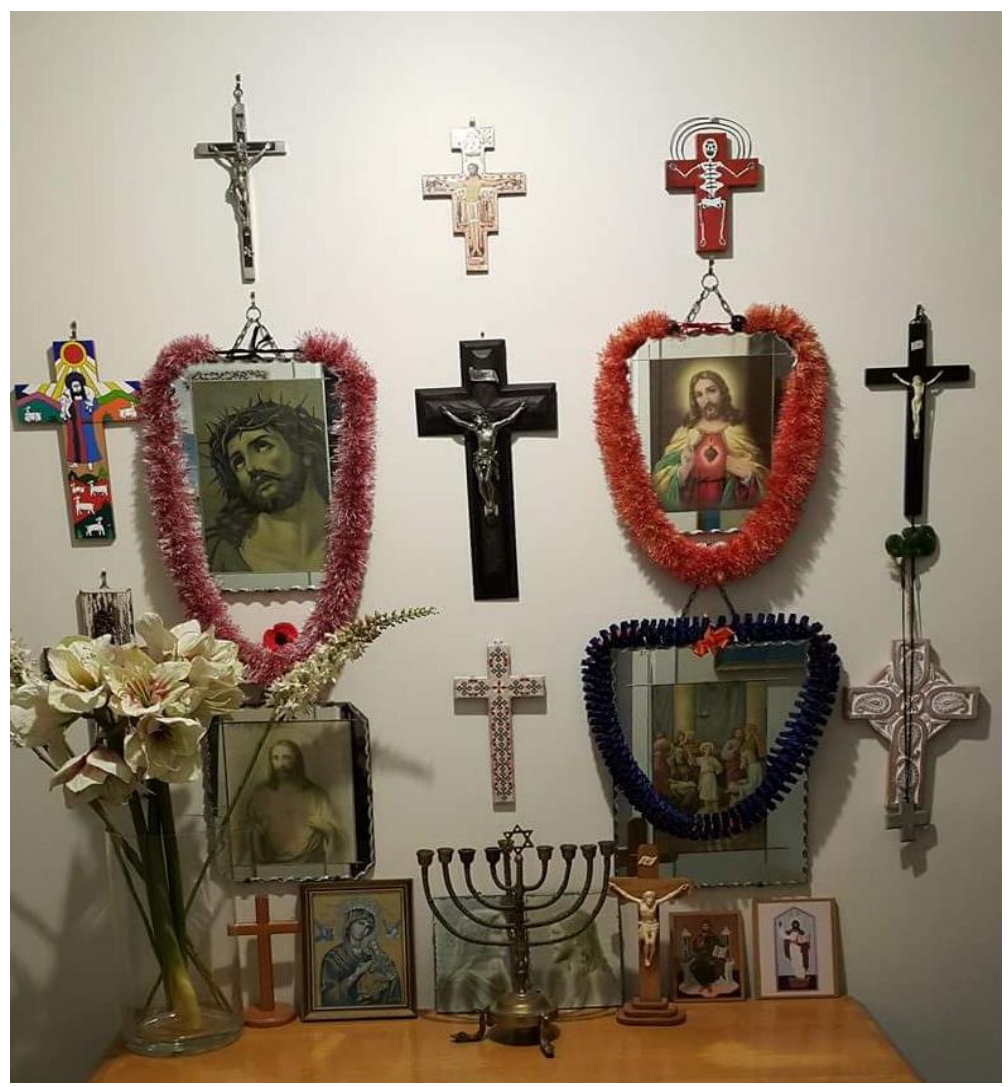

(B. Rangiwai, 2016, private collection)

I have referred to Jesus, very irreverently, on some occasions as a 'Jewish zombie'. This piece is a reflection on the idea that Jesus reminds me of the 'un-dead' in the zombie and vampire movies that I grew up watching in the 1980s. Here I use some forms of social media language and slang. 


\section{Jewish Zombie}

You challenged the status quo

Advocated for the poor and oppressed

You broke the rules

and hung out and partied

with all the hoodlums and rejects

You fought for the people sorted them out with jobs, free doctor's visits, fresh fruit and veges, bread and fish, warm dry homes, and heatpumps

You pissed off the power brokers

You f_cked with the establishment one too many times

You protested hard out

You're a radical, a revolutionary

Now you're behind bars

That warden is nasty $\mathrm{AF}$

He wants your head, real bad

Make an example

\#CrucifyHim!

Haters gon' hate

$+$

Rest in love, bro

\#FlyHigh

Sad that you died

*feeling heartbroken @ golgotha*

You were just too

good for this world

\#Cross \# Nails \#TombLife

On the cross you hung

For our sins you died

In GLORY you rose again

(that was freaky but neat)

In our hearts you live

forever

At the right hand

of your Father you sit

Heaven looks awesome

on your \# SnapChat 
Thanks for being dead

But \# NotDead \#ZombieJesus

www.zombiejesus.com

\section{Christology in my prayer life}

My grandmother taught me that karakia day and night was essential to life. We pray in the morning to ensure that we have a good day; and we pray at night to protect our wairua from harm as we sleep. That's the prayer life.

Image 3: Crucifix, Rosary beads, incense stick - a small
prayer space in my bedroom, Grey Lynn, Auckland

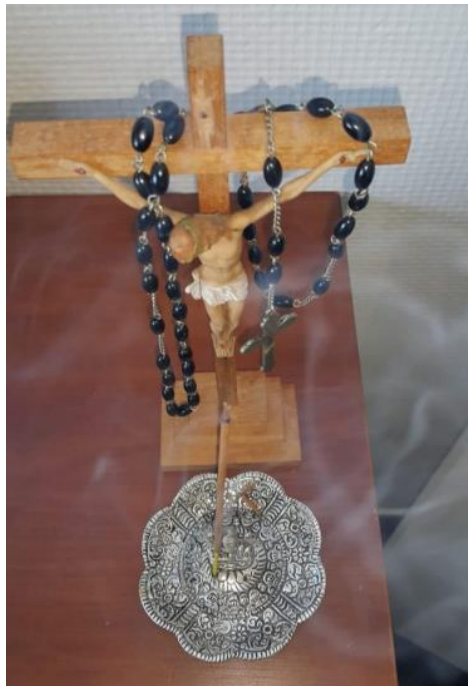

Morning prayers

Morning prayers begin with the burning of incense from an Indian shop

A tiny image of Lord Ganesh remover of obstacles decorates my incense stick holder

This is intentional My room reeks of Patchouli He hōnore, he korōria $\mathrm{Ki}$ te Atua Lord Jesus, watch over us this day and bless the whānau In nomine Patris et Filii et Spiritus Sancti Āmine

(B. Rangiwai, 2017, private collection). 


\section{Christology in my social life}

I am friends with people from literally ALL walks of life. I see Jesus almost everywhere. In film. On the streets. In the reflection of my glass of whiskey. Even in the face and presence of a drag queen on Ponsonby Road, posing as a warped version of the Virgin Mary. 


\section{Image 4: Lady Trenyce Bhone, SPQR Café and Bar, Ponsonby Road, Auckland}

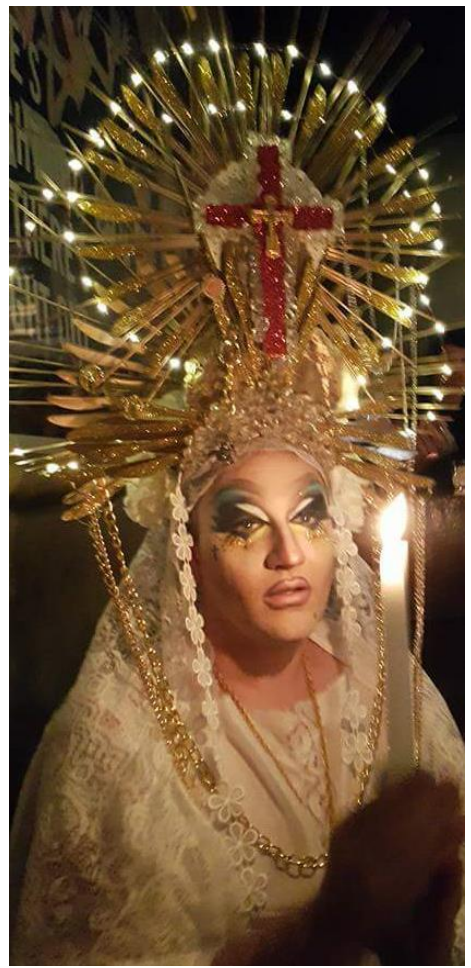

(B. Rangiwai, 2017, private collection)

\section{SPQR Jesus}

SPQR Jesus is caaamp!

She claps her hands

She does couture poses

and vogues while waiting tables

She fills the wine glasses

to the brim

and loves to see people

getting loved-up and

boozy

SPQR Jesus serves-up

Crayfish linguini

made by Polynesian chefs

who moved out of Ponsonby

'cos the rates were too high

\section{Lady Trenyce Bhone:}

"My performance is about the appropriation, by gay culture, of Christian, and in this case, Mariological iconography. This work evokes a feeling of gross imitation and defamation, underpinned, quite ironically, by a deep sense of admiration. In many ways, the blatant blasphemy of my replication defeats the iconic image of the Blessed Virgin, almost shaming her, suggesting that I am of a higher power than Mary. I am the embodiment of the "Virgin in a condom" (personal communication, June 22, 2018). 


\section{Christology in my devotion}

I always nod in the direction of a cross. I solemnly bow toward an altar. And I genuflect with both sincerity and drama when in the presence of a tabernacle. I attribute this respect toward crosses, crucifixes, altars and tabernacles or aumbries to both my Katorika and Mihingare whakapapa. My theology of the Eucharist is that it is the spiritual body and blood of Jesus and that I should venerate it. 


\section{Image 5: Altar, tabernacle and reredos/retable, ${ }^{1}$ St Mary's Cathedral, Sydney}

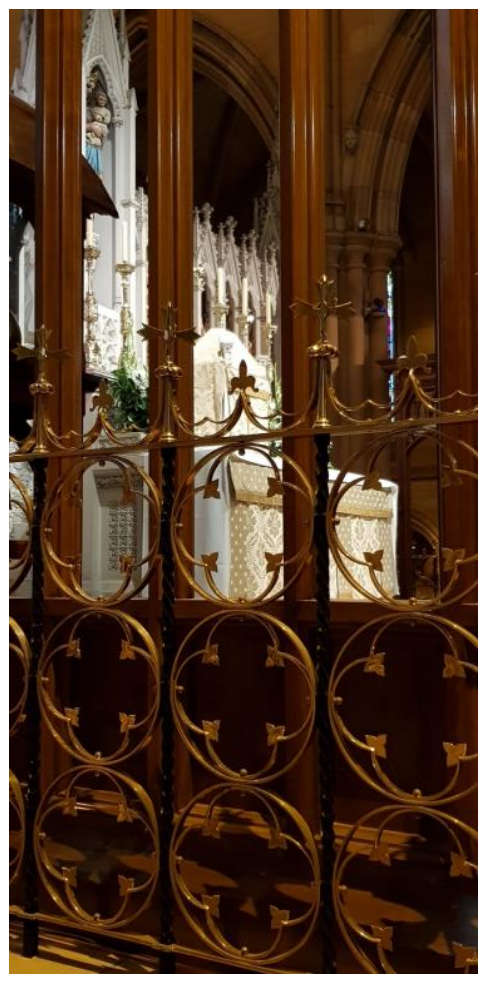

(B. Rangiwai, 2018, private collection)

\section{Jesus is home}

When Jesus is home he'll leave the light on But when the light is off Jesus is out shopping

Jesus is like a genie in a lamp he can fit into small spaces like a tabernacle or a chalice or on a shiny paten

The priest holds his fingers Together After handling the wafer For fear of dropping Jesus particles on the floor Feed the people with the BLOOD and FLESH of the un-dead Son

Rinse those pinchy Pincer-like fingertips with water and swish it round the blood-stained chalice

His portly face goes bright red when he swallows deeply the remainder of Christ's blood floaty bits 'n' all

1 At the time that I took this photograph I did not take notice as to whether there was a reredos or retable behind the altar. 


\section{References}

Baxter, J. K. (1988). Collected poems James K Baxter. Oxford, United Kingdom: Oxford University Press.

Brown, B. (2014). I am the Māori Jesus. In R. Whaitiri \& R. Sullivan (Eds.), Puna wai kōrero (pp. 54-55). Auckland, New Zealand: Auckland University Press.

Holman-Hunt, W. (1900-1904). Light of the world [painting]. Retrieved from: https:/ / www. stpauls.co.uk/ history-collections/thecollections/collections-highlights / the-light-of-the-world

Holman-Hunt, W. (1905). Pre-Raphaelitism and the pre-Raphaelite brotherhood. London, United Kingdom: Macmillan.

Osborne, J. (1995). One of us. Relish. Philadelphia, PA: The Crawlspace. 